\title{
Evaluation of Tax Administration and Tax Management at the Distributor of PT Pertamina Lubricants
}

\author{
(Case Study at PT Etam Wira Utama, Distributor of PT Pertamina Lubricant for North Kalimantan and Berau)
}

\author{
1 Graduate in Institut STIAMI, Jakarta - \\ 2 Graduate in Institut STIAMI, Jakarta \\ DOI: 10.29322/IJSRP.11.05.2021.p11312 \\ http://dx.doi.org/10.29322/IJSRP.11.05.2021.p11312
}

Muh. Takdir (BC201120014), Fs. Bahari (BC201120017)

\begin{abstract}
This research aims to understand and evaluate the tax administration and management applied at PT Etam Wira Utama. In terms of tax transactions, the regular monthly tax transactions which are often carried out by PT Etam Wira Utama are VAT, income tax article 21, income tax article 22, income tax article 23, as well as income tax article 25/29. The approach taken is a review on the concept of tax administration and management. We evaluate more deeply on how to map taxes in the company. Moreover, the process and the search of tax evaluation data on actual taxation principles, which are the Principle of Justice, the Principle of Certainty, the Principle of Convenience and the Principle of Economic. Guided by these principles, PT. Etam Wira Utama managed to become ranked ninth as a compliant taxpayer among thousands of corporate taxpayers throughout North and East Kalimantan in 2018.
\end{abstract}

Index Terms- Directorate General of Taxes (DJP), Tax Administration, Tax Management, Tax Principles.

\section{INTRODUCTION}

A company or institution can stand and continue to grow because of the support of resources and good management. Where every employee or staff has rights and obligations related to their work in a company. Administration is part of company management which includes data collection and arrangement of matters relating to various aspects of the company in order to be optimized. Administration is a term that is familiar in the world of work. The word administration is often associated with taking notes, correspondence and so on. This is what makes every institution, agency and company must have an administrative system. These activities are carried out by experts called administrators or administrative staff.

In daily life, administration has many functions both in the world of work and education. The administration can help facilitate both formal and non-formal work. Especially in terms of data management, administration makes it easier and more precise. Maybe during this time some of you often do administrative work but don't know that the work is a form of administration. For this reason, we will explain the understanding of administration in more depth below.

This publication is licensed under Creative Commons Attribution CC BY.

http://dx.doi.org/10.29322/IJSRP.11.05.2021.p11312
Tax is a citizen's obligation which is a form of service to the country whose reciprocity cannot be felt directly by the taxpayer and is coercive. Currently, the role of taxes as one of the backbone of state revenue is very important, because taxes are the main source of government financing and development. Tax dominance as a source of revenue is a natural thing, Since the number of natural resources is limited, tax as a source of revenue has an unlimited lifespan, especially with the increasing number of population so that tax becomes the main alternative in state revenue. Tax is dynamic, it follows developments in the social and economic life of the country and its people. Demands for increased revenues, improvements and fundamental changes in all aspects of taxation are the reasons for tax reform from time to time in the form of improvements to tax policies and tax administration systems, so that the tax base can be expanded, and the potential of available tax revenue can be collected optimally. by upholding the principle of social justice and providing excellent services to taxpayers.

The Official Assessment System is a tax collection system that authorizes the tax apparatus to determine the amount of tax owed annually in accordance with the provisions of the applicable tax laws. However, in its implementation, this system is considered inefficient because the procedures used are more timeconsuming, resulting in less optimal state tax receipt. Regardless, although the state is aggressively targeting increased tax revenues, taxpayers are trying their best to improve their administration and management in making tax deposits, collections and reporting without violating government regulations.

One of the State-Owned Enterprises which in tax terms contributes a considerable amount to the state is PT Pertamina Lubricants. PT Pertamina Lubricants in conducting marketing expansion cannot be separated from the assistance of its true partners, namely distributors which are spread throughout the archipelago. In almost every province of PT. Pertamina Lubricants has one distributor with a legal entity that is different from other distributors. Tax transactions which are routinely conducted by distributors in each month are related to tax transactions, in the form of income tax article 22, VAT, income tax article 21, income tax article 23, and income tax article 25/29.

Starting from the development of tax reporting that is required by the DGT for all taxpayers, it is considered necessary 
for taxpayers to manage taxation in a the concept of tax administration and management concept without carrying out activities that deviant from the taxation rules set by the DGT. Thus, based on this background, the author conducted research related to administration and taxation applied by the PT Pertamina Lubricants' Distributor where the case study was appointed at PT Etam Wira Utama, which is one of the distributors of PT Pertamina Lubricants.

\section{METHODOLOGY}

According to Sugiyono, research is a scientific way to obtain data with specific purposes and uses. Based on the type of approach, research can be divided into two types, quantitative and qualitative research. Quantitative research is conducted by explaining, testing, and determining the relationship between variables by sorting the problem into parts that can be measured or expressed in numbers. Quantitative research uses instruments or data collection tools that produce numerical data. Qualitative research produces descriptive data in the form of written words from people as well as observed behavior. The characteristics of qualitative research are as follows:

- Use a natural environment as a data source

- Has a descriptive analytical nature

- Emphasizes on process, not results

- Inductive (based on facts in the field)

- $\quad$ Prioritizing meaning

Starting from the definitions and characteristics of qualitative research described above, in principle this research uses a qualitative method approach that is a detailed approach in retrieving information related to the application of tax administration and management at PT Etam Wira Utama. PT Etam Wira Utama is one of the official distributors of PT Pertamina Lubricants, which located in North Kalimantan and Berau, The head office is located in Tarakan, North Kalimantan while its branch offices are in Berau, East Kalimantan and then several other units located in Nunukan and Tg. Selor in North Kalimantan.

\section{LITERATURE REVIEW}

\section{A. Administrative Sciences}

In general, the notion of administration is an activity or form of business that is closely related to various policy settings in order to achieve organizational targets. Thus it can be said that administration has a very crucial role for all company or organizational activities. This is what makes administration have a very important role so that the company continues to exist and continues to grow.

While narrowly speaking, administration is a form of activity that includes correspondence, note-taking, typing, simple bookkeeping and other activities of a technical nature. Administration can also be interpreted broadly, where administration is all processes of cooperation between several people with the aim of obtaining targets by utilizing certain facilities and infrastructure that have usability.
Administration is one of the important parts of a company. Because administration has several important functions, including the following:

\section{Planning}

Planning is an activity which requires an administrative activity starting from collecting data, processing data to arrange a plan.

\section{Organizing}

Administration serves as a constituent in an effort to build every communication and relationship between members or employees that is easily understood to achieve the goals of an organization or company.

\section{Coordinating}

As regulated by the organization or company, coordinating is carried out so that company activities can run smoothly and well so as to avoid clashes, activity vacancies and chaos. This can have a positive impact on the sustainability of a company in the future.

\section{Reporting}

Reporting is an activity to convey developments, movements and results of activities or programs carried out by employees and members to their superiors in writing. The report will later show the results of employee performance in accordance with the position and duties.

\section{Budgeting}

Budgets are important and must be in a company or organization to improve performance. In addition, the company also uses the budget to achieve its goals during the development period, which includes cooperation, advertising and so on.

\section{Staffing/Positioning}

Staffing deals with human resources in a company which includes the recruitment of experts, development and equipment needs.

\section{Directing or Guidance}

Directing is an activity of interaction with members of an organization or company in the form of guidance, orders or suggestions so that tasks can be carried out properly and are able to achieve specified goals.

Herbert A. Simon, an administrative expert from Europe, once issued a statement related to administration. He stated that when two men cooperate to roll a stone that neither one could have moved alone, the elements of administration have occurred.

\section{B. Management}

Whatever the purpose of an organization, all organizations must be composed of people who are members of the organization and a few individuals who help those people. These individuals are often referred to as managers. These managers combine and coordinate all resources to achieve organizational goals. All managers in any organization perform managerial functions or 
managerial activities, such as: planning and decision making, organizing, leading, and controlling.

"... Management ... can be defined as a set of activities (including planning and decision making, organizing, leading, and controlling) directed at an organization's resources (human, financial, physical, and information), with the aim of achieving organizational goals in an efficient and effective manner" (Griffin, 2013, p. 5).

According to Griffin, management is a process of planning, organizing, leading, and controlling the resources owned by the organization to achieve the goals effectively and efficiently. The organization's resources include human resources, financial resources, physical resources, and information resources.

Administration is the same as management, so that the entire process of activities and administrative dynamics is nothing but a process of activity and management dynamics.

William H. Newman: "There is clearly no distinction between administration and management. What is meant by the meaning of administration includes the meaning of management.

M.E Dimock, book: Public Administration: "Administration or management is a planned approach to solving all problems that mostly found in every individual or group, either state or private.

\section{Science of Tax Administration \& Tax Management Tax Administration}

Tax Administration is the recording, classification, storage and service of the obligations and rights of taxpayers conducted at the tax offices as well as at the taxpayer's office. Tax administration is in the interests of both the state as a tax collector and taxpayers as the executor of tax rights and obligations.

The process of filling out the Tax Return correctly and completely in accordance with the provisions is an important stage in tax administration. The incomplete and incorrect Tax Return filling will lead to fiscal sanctions, both administrative and criminal. If taxpayer submit theirr Annual Tax Return after the expiry of dateline, they will be sanctioned administratively in the form of fines. If taxpayers submits an incomplete Annual Tax Return, they will be threatened with criminal sanctions.

The criteria for a good tax administration are as follows:

- Must be able to secure state revenue.

- Based on legal tax law.

- Organizing an effective and efficient tax system.

- Implementation is ruled-based and transparent.

- Realizing legal taxation.

- Increase taxpayer compliance.

- $\quad$ Prevent all tax irregularities and provide fair sanctions and penalties.

The above criteria provide its own insights in evaluating good tax administration, of course, for taxpayers

Apart from the above, there are also some things about the concept of the Modern Tax Administration System. Information technology-based tax administration system will facilitate service and supervision to taxpayers and increase the productivity of tax officers' performance. This system will enable each taxation process to be more measured and controlled. A modern tax administration system supported by professional and quality Human Resources (HR) will create tax services that are based on transparency, independence, responsiveness, and fairness.

Some of the characteristics of the modern tax administration system are as follows:

- Tax administration is carried out through an information technology-based administration system.

- Taxpayers are required to pay online.

- Taxpayers are required to submit their Annual Tax Returns electronically (e-SPT).

- Intensive monitoring of taxpayer compliance.

The Directorate General of Taxes urgently needs modern tax administration reform in order to further improve services to taxpayers and to supervise the implementation of taxation in accordance with the principles of good corporate governance. On the other hand, with tax administration reform, taxpayers are expected to be able to get better tax services so that tax problems can be resolved more quickly with more secure legal certainty. Taxpayers' rights and obligations will be carried out smoothly in accordance with applicable regulations. The prospect is far ahead, the implementation of an optimal modern tax administration system will increase satisfaction with taxpayers. Good taxation services will make it easier for taxpayers to carry out their tax obligations, thereby increasing the potential for tax revenue in Indonesia.

\section{Tax Management}

Tax management is a process of planning, organizing, directing, and controlling resources to make tax payable payments effectively and efficiently. Effective means that the goal of tax savings can be achieved in accordance with the tax planning which has been created and determined. Efficient means that existing tasks are carried out correctly, organized, and in accordance with the planning that has been decided (Prianto Budi S: Tax Management, p. 86).

Quoted from Suandi (2011, p. 6), Lumbantoruan defines tax management as follows:

"Tax management is a tool to fulfill tax obligations properly but the amount of tax paid can be kept as low as possible to obtain the expected profit and liquidity".

Furthermore, according to Lumbantoruan, the objective of tax management is to properly implement tax regulations as an efficiency effort to achieve expected profit and liquidity. The objectives of tax management can be achieved through tax management functions which consist of:

1) Tax Planning,

2) Tax Implementation, and

3) Tax Control

Another definition is quoted from Pohan (2015, p. 13). Pohan defines tax management as follows: 
"Taxation Management is a comprehensive effort conducted by tax managers in a company or organization so that matters related to taxation of the company or organization can be managed properly, efficiently, and economically, thus provides maximum contribution to the company".

According to Griffin, the goals of management in an organization are efficiency and effectiveness. Thus, the objective of tax management is the effective and efficient implementation of tax obligations. The effective implementation of tax obligations means that goals can be achieved in accordance with tax planning, while being efficient means that tasks are carried out correctly, organized, and on schedule.

\section{Income-Based Tax}

One approach in determining the tax base is to impose taxes on income. This approach then raises the question: what kind of income will be taxed? In general, income is an additional economic capability received / obtained by a person within a certain period of time. The definition of income in taxation itself cannot actually be that simple. The definition of income in taxation must be an understanding that provides fairness and can be implemented (applicable). Schanz, Haig and Simon (SHS Concept) suggest the following definition of income:

1) George Schanz suggests that the definition of income for tax purposes should not differentiate the sources and ignore its use, but rather emphasize the economic capabilities that can be used to control goods and services (Mansury in Rosdiana and Irianto, 2012);

2) Haig defines income as the money value of the net accretion to one's economic power between two points of time;

3) Henry C. Simon argues that individual income broadly means the utilization of control over the limited use of community resources. Furthermore, Simon develops the following definition of income: Personal income may be defined as the algebraic sum of (1) the market value of rights exercised in consumption and (2) the change in the value of the store of property rights between the beginning and the end of period in question. In the words, it is merely the result obtained by adding consumption during the period to 'wealth' at the end of the period and then subtracting 'wealth' at the beginning.

The definitions above are in line with the definition of income adopted in the Income Tax Law (Article 4) which reads:

"The object of income tax is income, which is any additional economic capability received or obtained by taxpayers, both from Indonesia and outside Indonesia, which can be used for consumption or to increase the wealth of the taxpayer concerned, under whatever name and form.

As a consequence of choosing the definition of income as an additional economic capability, it must be determined precisely which additional economic capacity is subject to tax. Likewise, it has to be determined about what tax reliefs are allowed which really reflect the actual additional economic capabilities.

Mansury, in Rosdiana and Irianto (2012) tells that when Indonesia underwent its first tax reform in 1984, the selection of tax objects in the process of drafting the 1984 Income Tax system revolved around the issues of (i) whether to use a definition of income based on the principle of sources or the principle of additional economic capability; (ii) what costs are permitted in calculating the taxable income; (iii) which depreciation method will be adopted in accordance with the objectives to be achieved in the 1984 tax system; and (iv) how to calculate taxable income, including how to calculate the Taxpayer's non-taxable income (PTKP) to be deducted from net income in obtaining taxable income.

Income tax is tax imposed on an individual or entity on income received or earned in a tax year. The income referred to can be in the form of business profits, salaries, honorariums, gifts, and others.

There are several types of Income Tax such as Income Tax Article 15, Income Tax Article 19, Income Tax Article 21, Income Tax Article 22, Income Tax Article 23, Income Tax Article 24, Income Tax Article 25, Income Tax Article 26, Income Tax Article 29 and Final Income Tax Article 4 paragraph 2. In Indonesia income tax was initially applied to plantation companies which were widely established in Indonesia. The tax is embedded with corporate tax.

Corporate tax is a tax imposed on company profits and enforced in 1925. After the tax is only imposed on companies established in Indonesia, the tax finally gradually imposed on individuals or employees who work in a company.

In 1932 the so-called income tax ordinance was introduced. This income ordinance is imposed on Indonesians as well as people who are not residents of Indonesia but have income in Indonesia. In 1935 a wage tax ordinance was enacted requiring employers to deduct an employee's salary or wages in order to pay tax on the salary received.

Brief description of Income Tax are as follows:

1. Income Tax Article 15

2. Income Tax Article 19. Related to asset revaluation. The tax object of Income Tax Article 19 is tangible assets either land or buildings which have property rights or rights-of-use of building. Other fixed assets which are located in the country and are used to collect and maintain income also become the object of Income Tax Article 19.

3. Income Tax Article 21 is withholding tax for income from work, services, or activities under any name and form that is received or obtained by individual domestic taxpayers.

4. Income Tax Article 22 is an income tax imposed on certain business entities, both government and private, which carry out export, import and re-import trade activities. Some of the activities which are included in the type of Income Tax article 22 are the delivery of goods; activities in the import sector or business activities in other fields; and purchases of goods that are classified as very luxurious.

5. Income Tax Article 23 is a levy imposed on income on capital, delivery of services or gifts and awards, other 
than those which have been deducted from Income Tax Article 21.

6. Income Tax Article 24 is a regulation regarding the rights of taxpayers to utilize their tax credits paid abroad on income derived from abroad, to reduce the tax payable in Indonesia.

7. Income Tax Article 25 is payment in the form of tax installments originating from the amount of payable income tax according to the Annual Tax Return less withheld or collected income tax and income tax paid or payable abroad which may be credited.

8. Income Tax Article 26. This type of income tax is imposed on income originating from Indonesia received or earned by foreign taxpayers other than a permanent establishment in Indonesia.

9. Income Tax Article 4 paragraph (2) is tax on income which is final and cannot be credited with payable income tax.

\section{E. Principles of Taxation}

In supporting the smooth running of the tax collection system in order to run effectively, there are four tax principles that must be implemented in the implementation of tax collection. The four tax principles are as follows:

\section{The Principle of Justice (Equity)}

Vertical justice and horizontal justice in tax collection must be fulfilled. The principle of fairness essentially pays attention to the imposition of taxes in general and in accordance with the ability of the taxpayer or proportional to the level of income. Horizontal justice is that taxpayers with the same or equal conditions will be subject to the same tax burden. Meanwhile, horizontal fairness is when taxpayers with a larger amount of income will bear a larger tax burden than taxpayers with small income. Fairness in tax collection means that taxes are imposed in general and in accordance with the ability of the taxpayer or in proportion to the level of income.

\section{The Principle of Certainty}

Tax collection must be carried out firmly, clearly, and there is legal certainty and guarantee. The principle of certainty provides convenience for taxpayers regarding the object of tax imposition, the amount of tax or tax base, as well as all procedures for fulfilling tax obligations. This is intended to make it easier for taxpayers to understand and facilitate administration

\section{The Principle of Convenience}

The tax collected should not be burdensome to the taxpayer and should be in line with the self assessment system. This means that the government prioritizes and pays attention to whether a person is worthy or not to be taxed, so that people who are taxed will be happy and sincere to fulfill and pay their tax obligations.

\section{Principles of Economy}

When determining and collecting taxes, it must consider the cost of tax collection and must be proportional. The government will implement an effective and efficient tax system, such as low tax collection costs. Do not let the collection fee be higher than the tax burden imposed.
Taxpayer accountability is an important benchmark in tax reporting, since accountability is an element of democracy. Accountability is defined as a tool to be able to account for one's actions and behavior. Whoever is the actor of the organization, accountability is needed legally in terms of being responsible for his actions

Those are brief discussions of the four tax principles which must be applied in Indonesia. In order to carry out effective and efficient tax collection, it would be best if these four tax collection principles should be prioritized. Proud to pay taxes. Of course, after paying, the next process is to report the tax itself.

\section{DISCUSSIONS AND RESULTS}

\section{Tax Mapping for PT Pertamina Lubricants Distributor Company}

The Tax Mapping Process will assist in compiling, managing and preparing the Corporate Annual Tax Return from the start. The tax transactions for PT Etam Wira Utama are as follows:

1. Income Tax Article 22

The Income Tax Article 22 transaction is a lubricant purchase transaction for distributors to the principle or PT. Pertamina Lubricants with a rate of $0.30 \%$. The distributor still receives withholding tax slip of Income Tax Article 22 even though it is received one month after the Sales Order is issued from the principle. According to existing regulations, withholding tax slip should be given to the buyer at the time the transaction has been made even though it is a non cash transaction. However, since PT Etam Wira Utama is a distributor, it must comply with PT Pertamina Lurbicants as a principle even though the withholding tax slip was received too late by the Distributor.

If the Company doesn't have a certain application to summarize everything, at least they can use the Microsoft Excel to record and accumulate Income Tax Article 22 each week, so that later during the preparation process for the Annual Corporate Tax Return, it can ease the preparation process.

The total Gross Sales Price stated on the Withholding Tax Slip of Income Tax Article 22 must be the same as the purchase amount in the Income Statement. When the value is not the same, especially if the number is lower, then there is an indication that it is not reported, and vice versa if the value is high, it is possible that there is a double reporting.

\section{VAT}

There are two VAT transactions for PT Etam Wira Utama : Output VAT and Input VAT. Output VAT is all tax invoices made for sales to all consumers, while Input VAT is a tax invoice received for purchases. In internal recording, it was recorded as VAT Payable. In addition to the issuance of the tax invoice, the company also prepares tax invoice "gunggungan".

The majority of purchases are to principle, other than that some purchases are made only for operational needs, nominally not too significant for the effect of the input tax. The total tax base 
as a whole, the purchase value cannot be compared with the total tax base as a whole, the total Income Tax Article 22 issued because of the principle. Because Input VAT is not only from purchases to principle but more than that some Input VAT comes from purchases other than PT Pertamina Lubricants.

Monthly Report VAT can be recorded each month using a simple application such as Microsoft. Excel. Every time you finish reporting the Monthly Report, input the simple data, so that later at the end of the year you can easily calculate the data.

\section{Income Tax Article 21}

Income Tax Article 21 is closely related to employees. PT Etam Wira Utama applies the net system. Each monthly Income Tax Article 21 report is created a special database to calculate the total in a year so that at the end of the year the total value is immediately visible. The method applied is the Gross Up method. The company pays Income Tax article 21 for each employee, both on a monthly salary basis as well as the receipt or disbursement of severance pay for both retired employees. By recording employees' income tax article 21 as the company's expenses, this is a certain indication for the management of the company regarding its high appreciation for its employees. All tax expenditures are issued and reported in real terms to the DGT without tax evasion.

\section{Income Tax Article 23}

Income Tax Article 23 transactions are due to transportation services to PT PLN Persero and to PT Pertamina Lubricants' main customers. The sale of lubricants to PT PLN is separate from the freight service, while the delivery transportation services to the main customer of PT Pertamina Lubricants are served because of the responsibility of PT Etam Wira Utama as a distributor for the North Kalimantan and Berau Regions even though lubricants are directly purchased to principle. Related to this, the distributor's duty is not only trading but also has to provide services for certain customers.

There are several customers of PT. Pertamina Lubricants which are not the distributor's customers. However, the distribution is the responsibility of the distributor. The supply is related to transportation. This transportation is related to the Income Tax Article 23 transaction. In addition, as stated above, one of the examples is PLN. According to the lubricant agreement, sales made to PLN are only in the form of lubricants, not transportation. Therefore when the distributor of supplies or making deliveries to each PLN site, the company was not only make a sales invoice of but also made a separate invoice for transportation service.

\section{Income Tax Article 4 (2)}

Transactions for Income Tax Article 4 (2) are for leasing buildings and offices and dividend disbursement by company owners. These transactions are quite rare among other tax transactions. The building lease referred to the head office which actually belongs to one of the management and does not belong to the company. The company rented the building for office operations. The building lease also referred to each lease for each branch office of PT Etam Wira Utama. Dividend disbursement, if any, is reported immediately after the transaction.

\section{Income Tax Article 25/29}

Income Tax Article 25/29 is recorded as payment since the current Annual Tax Return is reported. Tax collection and reporting are consistently carried out as a form of taxpayer compliance.

\section{Tax Planning \& Annual Corporate Tax Return}

Tax Planning's coverage is quite broad. However, this time we are more focus on discussing the process of preparing, compiling, processing and controlling data related to the Annual Corporate Tax Return in order to be prepared earlier so that at the time of compiling the Annual Corporate Tax Return, it will not burden the taxpayer. It is undeniable that the preparation of the Annual Corporate Tax Return is quite burdensome for both taxpayers and taxpayer proxies.

In various articles that are often found on the internet, in general, these articles discuss more technically preparing the Annual Corporate Tax Return and rarely do they discuss the strategy of preparing, controlling and managing the Annual Corporate Tax Return so that it can be reported on time and without rushing to finish it.

Employees who handle taxes in the company should carry out specific strategies and tactics so that the completion of tax reports can be finished on time. Taxes that we all know are reports that are intended for external purposes are not the same as other reports that are intended for internal purposes of the company. The majority of internal purpose reports still have certain tolerances which are lighter compared to reports that are external purpose reports

According to Article 3 paragraph (1) of the General Provisions and Tax Procedures Law and its explanation, tax return must be completed correctly. Correctly means correct in calculation, including correct in the application of provisions of taxation law, in writing, and in accordance with the actual situation. Complete means contain all elements relating to tax objects and other elements that must be reported in the tax return. Clear means we have to report the origin or source of the tax object and other elements that must be reported in the tax return. Completion of the Annual Tax Return correctly, completely and clearly is important and must be done if we want our company's Annual Tax Return to run smoothly. If the submission is not in accordance with the law, it may result in the Annual Tax Return being declared "Incomplete" or "Not Delivered".

Even though we already understand technical input in the Corporate Annual Tax Return system, if we do not understand the source and process of the data, it is very possible to hinder the preparation of the Annual Corporate Tax Return.

PT Etam Wira Utama also frequently received letters from the Tarakan Tax Office, North Kalimantan, in the form of a Tax Collection Letter, Request for Explanation of Data and so on. The method used is Communication Soft skill. PT Etam Wira Utama immediately responded verbally to the Tarakan Tax Office, the principle is that communication and response are the most 
important and of course the local tax authorities will definitely appreciate it even though a written response will follow.

In 2018 PT Etam Wira Utama received an award as an obedient Corporate Taxpayer, ranked at 9th place out of thousands of Corporate Taxpayers in East and North Kalimantan. This award proves in a way that PT Etam Wira Utama is an obedient a corporate taxpayer which also applied the principles of taxation: the Principle of Justice, the Principle of Certainty, the Principle of Convenience and the Principle of Economic.

\section{CONCLUSION}

Companies engaged in distributors such as PT Etam Wira Utama, in terms of transactions, have a very intense buying and selling or trading transactions. In trading companies, there are a lot of VAT transactions, both Input VAT (Purchase) and Output VAT (Sales). Other than VAT, PT Etam Wira Utama also carries out other regular tax-related transactions, in the form of Income Tax article 21, Income Tax article 23, Income tax article 25/29 and Income Tax article 4 (2) although the last one is rarely happened.

These types of taxes are closely related to the calculation of the Annual Corporate Tax Return. PT Etam Wira Utama manages tax administration in a fairly stable tax management. Long before the Corporate Annual Tax Return was reported, all relevant taxes were already fixed and checked, because the tax management and administration were already very good.

PT Etam Wira Utama also frequently received letters from the Tarakan Tax Office, North Kalimantan, in the form of a Tax Collection Letter, Request for Explanation of Data and so on. The method used is Communication soft skill. PT Etam Wira Utama immediately responded verbally to the Tarakan Tax Office, the principle is that communication and response are the most important and of course the local tax authorities will definitely appreciate it even though a written response will follow.

The concept of Tax Administration and Management applied at PT Etam Wira Utama is already in line with the universal tax policy principles: Principles of Justice, Principles of Certainty, Principles of Convenience and Principles of Economic. According to us, one of the universal benchmarks is that in 2018, PT Etam Wira Utama was ranked ninth out of thousands of corporate taxpayers as compliant corporate taxpayers.

\section{REFERENCES}

[1] Saintif, 2020. Administrasi: Pengertian, Tujuan, Fungsi, dan Cirinya [LENGKAP]. https://saintif.com/administrasi-adalah/. Accessed on 5 April, 2021.

[2] Idcloudhost, 2020. Pengertian Administrasi: Pengertian, Fungsi, Tujuan dan Cara Kerjanya. https://idcloudhost.com/pengertian-administrasi-pengertianfungsi-tujuan-dan-cara-kerjanya/. Accessed on 5 April, 2021.

[3] Ismowati, Mary, 2020. Handout Perkuliahan Konsep Dan Teori Administrasi Publik Kontemporer. Jurusan Administrasi, Konsentrasi Manajemen Perpajakan : Tidak Diterbitkan.

[4] Budi S, Prianto, 2016. Manajemen Pajak. Jakarta: PT Pratama Indomitra Konsultan.

[5] Sangkala, 2012. Manajemen Publik. Yogyakarta : Penerbit Ombak.

[6] Pemerintah Indonesia. 2008. Undang-Undang No. 208 Tahun 2007 Yang Mengatur Tentang Ketentuan Umum dan Cara Perpajakan. Lembaran RI Tahun 2007 No. 39. Jakarta : Sekretariat Negara.

[7] PT Mid Solusi Nusantara, 2021. Sistem Administrasi Pajak Modern Optimalkan Penerimaan Pajak. https://klikpajak.id/blog/tips-pajak/sistemadministrasi-pajak-modern/. Accessed on 8 April, 2021.

[8] Onlinepajak, 2016. PPh Pasal 24 (Pajak Penghasilan Pasal 24). https://www.online-pajak.com/tentang-pph-final/pph-pajak-penghasilanpasal-24/. Accessed on 8 April, 2021.

[9] Onlinepajak, 2016. Ini Jenis Pajak Penghasilan yang Sering Bersinggungan dengan Anda. https://www.online-pajak.com/tentang-pph21/ini-jenis-pajakpenghasilan-yang-sering-bersinggungan-dengan-anda. Accessed on 8 April, 2021.

[10] Harmony, 2021. PPh Pasal 19 Atas Revaluasi Aktiva, Ini Ketentuan Lengkap Dan Contohnya. https://www.harmony.co.id/blog/pph-pasal-19-atasrevaluasi-aktiva-ini-ketentuan-lengkap-dan-contohnya. Accessed on 8 April, 2021.

[11] Prabandaru, Ageng, 2021. Mengenal 4 Prinsip Pajak yang Wajib Dipungut di Indonesia. indonesia/. Accessed on 8 April, 2021.

\section{AUTHORS}

First Author - Muh. Takdir (BC201120014), Graduate in Institut STIAMI, Jakarta

Second Author - Fs. Bahari (BC201120017), Graduate in Institut STIAMI, Jakarta 